\title{
A STAND FOR DESIGNING AND TESTING THE OPERATIONAL MODES OF THE SUBSYSTEMS OF THE HYBRID MULTICOPTER MOTOR
}

\author{
Akhmedov D.Sh. ${ }^{1}$, Samsonenko A.I. ${ }^{2}$, Raskaliyev A.S. ${ }^{3}$, Boguspayev N.B. ${ }^{4}$ \\ ${ }^{1}$ Akhmedov Daulet Shafigullovich - Doctor of Technical Sciences, Chief Researcher; \\ ${ }^{2}$ Samsonenko Anatoliy Ivanovich - Chief Engineer; \\ ${ }^{3}$ Raskaliyev Almat Serikovich - PhD, Research Associate; \\ ${ }^{4}$ Boguspayev Nurlan Bolatkarimovich - Lead Engineer, \\ INSTITUTE "GEOGIPROPROEKT", \\ ALMATY, REPUBLIC OF KAZAKHSTAN
}

\begin{abstract}
: the structure and composition of the experimental sample of the stand for working out the modes of various modules and subsystems of a hybrid engine for multicopters are considered. A model sample of the hybrid engine is placed on the stand, and the output of this stand is fed at the same time by an internal combustion engine and an electric generator, that allows crosschecking the measured parameters. This article also presents the structural diagram of the stand for experimental testing of the modes of operation of the mounts and subsystems of the hybrid engine.
\end{abstract}

Keywords: hybrid engine; model sample; stand; testing operational modes.

\section{СТЕНД ДЛЯ ТЕСТИРОВАНИЯ И ОТРАБОТКИ РЕЖИМОВ РАБОТЫ ПОДСИСТЕМ ГИБРИДНОГО ДВИГАТЕЛЯ ДЛЯ МУЛЬТИКОПТЕРОВ Ахмедов Д.Ш. ${ }^{1}$, Самсоненко А.И. ${ }^{2}$, Раскалиев А.С. ${ }^{3}$, Богуспаев Н.Б. ${ }^{4}$ Email: Akhmedov1138@scientifictext.ru}

\author{
${ }^{1}$ Ахмедов Даулет Шафигуллович - доктор технических наук, главный научный сотрудник; \\ ${ }^{2}$ Самсоненко Анатолий Иванович - главныий инженер; \\ ${ }^{3}$ Раскалиев Алмат Серикович - доктор философии (PhD), научный сотрудник; \\ ${ }^{4}$ Богуспаев Нурлан Болаткаримович - ведущий инженер, \\ Институт «Геогипропроект», \\ 2. Алматы, Республика Казахстан
}

\begin{abstract}
Аннотация: рассмотрены структура и состав экспериментального образца стенда для отработки режимов различных модулей и подсистем гибридного двигателя для мультикоптеров. Макетный образеи гибридного двигателя помещается на стенд, к выходу которого одновременно подается напряжение двигателем внутреннего сгорания и электрическим генератором, что позволяет проводить перекрестную проверку измеряемых параметров. $B$ этой статье также представлена структурная схема стенда для экспериментального тестирования режимов работы узлов и подсистем гибридного двигателя.
\end{abstract}

Ключевые слова: гибридный двигатель, макетный образеи, стенд, тестирование рабочих режимов.

UDC 621.313 .15

A hybrid engine (HE) is a source of power in the unmanned aerial vehicle (UAV) [1] designated for additional power supply to the multi-copter actuators, its electric motors, as well as for replenishing the charge of the onboard battery, and solving the following tasks: levels;

- supporting charge of the on-board battery between the minimum permissible and the maximum permissible

- switching off the internal combustion engine when the battery reaches its maximum permissible charge level (optimal value is $80 \%$ of the charge);

- turning off the HE at certain stages of the mission UAV (for example, for photo or video shooting in order to reduce the noise and vibration from the internal combustion engine (ICE);

- re-enabling the HE after the shooting is completed;

- providing an output power of at least 350 watts.

The developed model sample of the hybrid engine for the multicopter GGP-0405.001 is an electromechanical system consisting of an internal combustion engine and an electric generator connected by a transmission mechanism, as well as an onboard battery. The main source of energy for the actuators of the multicopter is the onboard accumulator battery (AB). The HE is activated before take-off of the UAV to save battery power and increase the flight duration. During the flight, the HE is switched on for periodic recharging of the battery and when the maximum required level of charge is reached, the internal combustion engines and the electric generator (EG) are switched off. 
The flight duration of a helicopter-type UAV, a multi-copter, with a mass of up to $10 \mathrm{~kg}$ and a payload weight of not more than $3 \mathrm{~kg}$, is $20 \div 25$ minutes and it is limited by the final capacity of the battery. This is a very common class of multicopters, allowing you to make use of, for example, a quality photo or video camera as a payload. Such multicopters use lithium-polymer batteries with a capacity of $10000 \div 16000 \mathrm{mAh}$ and weighing up to $3 \mathrm{~kg}$. Increasing the capacity to increase the flight duration of the battery is not productive due to a significant increase in the weight of the battery itself.

The proposed for installation on board micro-class HE (weight up to $10 \mathrm{~kg}$ ) and the corresponding size, as an additional source of energy, could prolong the flight to $40 \div 45$ minutes, that is, multiply the flight time of the multicopter by two or more times.

The model sample of the hybrid engine includes the following components [2]:

- Internal combustion engine (ICE) designed to work as a mechanical drive converting the calorific value of fuel into mechanical work in the form of rotational movement of the output shaft,

- Electric generator (EG) designed to convert the mechanical work of rotary motion, on the input shaft, into electrical energy,

- Fuel tank (FT) designed to power the internal combustion engine,

- The accumulator battery $(\mathrm{AB})$ is a chemical re-chargeable current source, the main specificity of which is the reversibility of internal chemical processes, which ensures its repeated cyclic use for energy storage and autonomous power supply of multicopter type UAV's electric engines.

- Transmission mechanism (TM), a mechanical device designed to transfer movement from one body to another. In this case, the TM serves to transfer the rotational motion of the output shaft of the ICE to the input shaft of the EG.

When carrying out the design work, in particular, for determining the load characteristics of the electric generator under consideration, comparing the qualitative and mass-dimensional parameters of various rectifiers based on high-speed diodes, it is impossible to determine the dynamic characteristics of the analyzed power generators and solve many other problems without full-scale experiments. To find out the specification of technical parameters when creating an experimental sample of HE, as a rule, a model or a model sample is developed. Then the model sample provides an opportunity to carry out field experiments.

A model sample is a simplified reproduction of a prototype or a part of the prototype reduced on a certain scale, on which its individual characteristics are examined, and the correctness of the technical decisions made is evaluated. The term "model sample" is usually used for a model in which the quantitative relationships between the elements of a product are preserved and its certain properties are modeled [3].

To solve the problems mentioned above, a model sample of the hybrid engine and a stand for developing and testing the hybrid engine and its subsystems were developed.

The composition of the model sample of the hybrid engine includes the following components:

- Internal combustion engine Vertex 18 Engine;

- Electric motor Arrowind 2815-09 Brushless Out-runner Motor;

- Transmission mechanism, which was tested as a possibility of a rubber and plastic pulley;

- Burden, which was used as a laboratory automatic transformer controlled (LATC) Delixi 1000VA.

The internal combustion engine Vertex 18 Engine, used in the model sample, is a carburetor glow-engine operating on nitromethane, two-stroke, and it's rotation speed is hold from 3000 to 20,000 revolutions per minute. The feature of this engine is the ignition of the fuel-air mixture in the cylinder with a glow plug. The main parameters of the ICE Vertex 18 Engine [4] are presented in Table 1.

Table 1. The main parameters of the internal combustion engine Vertex 18 Engine

\begin{tabular}{|c|c|c|}
\hline № & Parameters & Values of the parameters \\
\hline 1 & Output shaft rotation speed, rpm & $3000 \div 20000$ \\
\hline 2 & Volume of the cylinder, cu. cm & 2,95 \\
\hline 3 & Diameter of output shaft, $\mathrm{mm}$ & 14,5 \\
\hline 4 & Weight, gr. & 258 \\
\hline 5 & Carburetor & Rotary with side release of exhaust gases \\
\hline
\end{tabular}

Electric motor BL2815/09 920KV Series Brushläss Outrunner Motor, brushless, used in the model sample as an electric generator, has the technical characteristics presented in Table 2.

Table 2. The main technical characteristics of the electric motor BL2815/09 920KV Series Brushless Outrunner Motor

\begin{tabular}{|c|c|}
\hline Parameters & Value \\
\hline $\mathrm{kV}$ number of revolutions per 1 volt & 920 \\
\hline Stator dimensions, $\mathrm{mm} \times \mathrm{mm}$ & $30 \times 15$ \\
\hline Shaft diameter, $\mathrm{mm}$ & 5 \\
\hline Model weight, $\mathrm{gr}$ & 1000 \\
\hline
\end{tabular}


The burden is a laboratory automatic transformer controlled (LATC) - Delixi 1000VA BK-1000VA 380V 220V 110v 24v 36v 12v 1000W, which has the characteristics shown in Table 3.

Table 3. The main technical characteristics of the electric motor BL2815/09 920KV Series Brushless Outrunner Motor

\begin{tabular}{|c|c|c|}
\hline № & Parameter & Value \\
\hline 1 & Manufacturer & Delixi \\
\hline 2 & Type of frequencies & Low frequencies \\
\hline 3 & Cooling system & Dry type \\
\hline 4 & Range of voltage change, V & $12-380$ \\
\hline
\end{tabular}

Figures 1 and 2 show a model sample of the hybrid engine placed on the stand, to the output of which a load model is incorporated and the Delixi LATR feeds it.
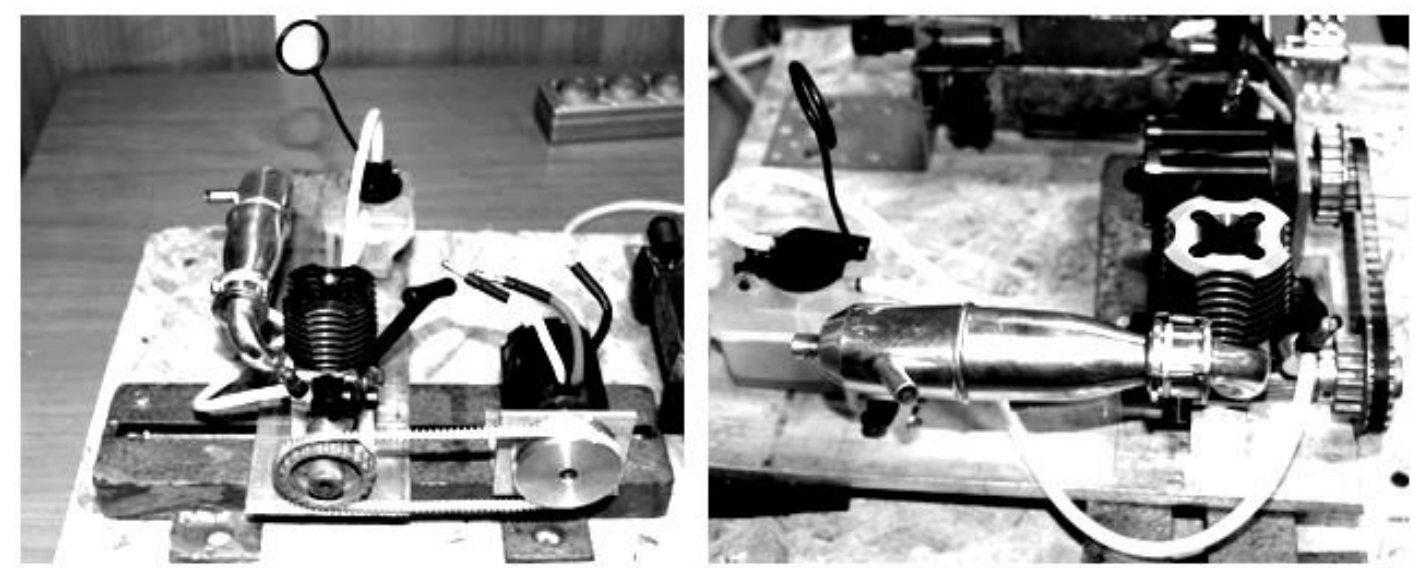

Fig. 1. A model sample of the hybrid engine
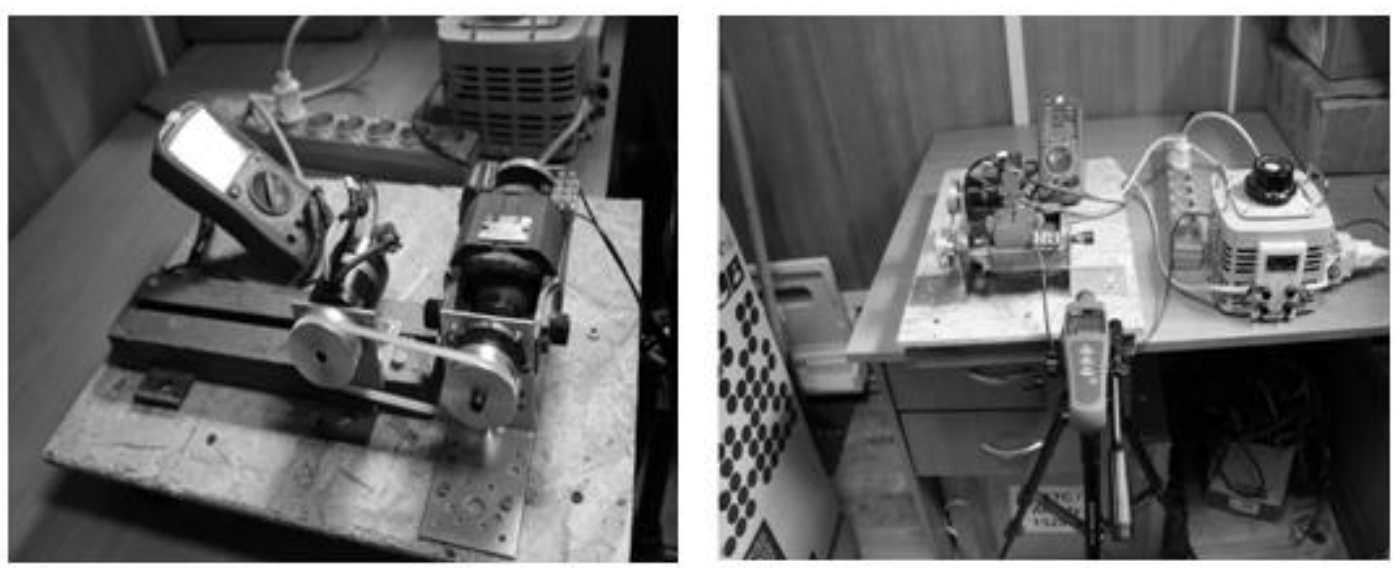

Fig. 2. The model sample on the stand for the investigation of the cur-rent-voltage characteristics of an electric generator

The long wires of the converter are the input, connected in a $220 \mathrm{~V}$ network, and on its output (short wires) $13 \mathrm{~V}, 1.8 \mathrm{~A}$ is connected to the ends of the oscilloscope to obtain a sinusoidal burden [5].

The stand for experimental testing of modes of various HE modules is designed for:

- determination of the load characteristics of the EG N5065 at various revolutions with the drive from the electric motor ELMO 1019;

- determination and comparison of qualitative and mass-dimensional parameters of the three-phase rectifiers on the basis of high-speed diodes, and on the basis of a synchronous rectifier, when working with EG N5065;

- determination of dynamic characteristics of EG N5065 with drive from ICE;

- testing automatic speed of the internal combustion engine when changing the generator's burden;

- testing of the starter modes of the hybrid engine, starting and warming up the ICE and switching to the generator mode;

- testing of the software part of the charging and starting automatics.

The structural diagram of the stand for experimental testing of the modes of operation of the mounts and subsystems of the HE is shown in Figure 3. 


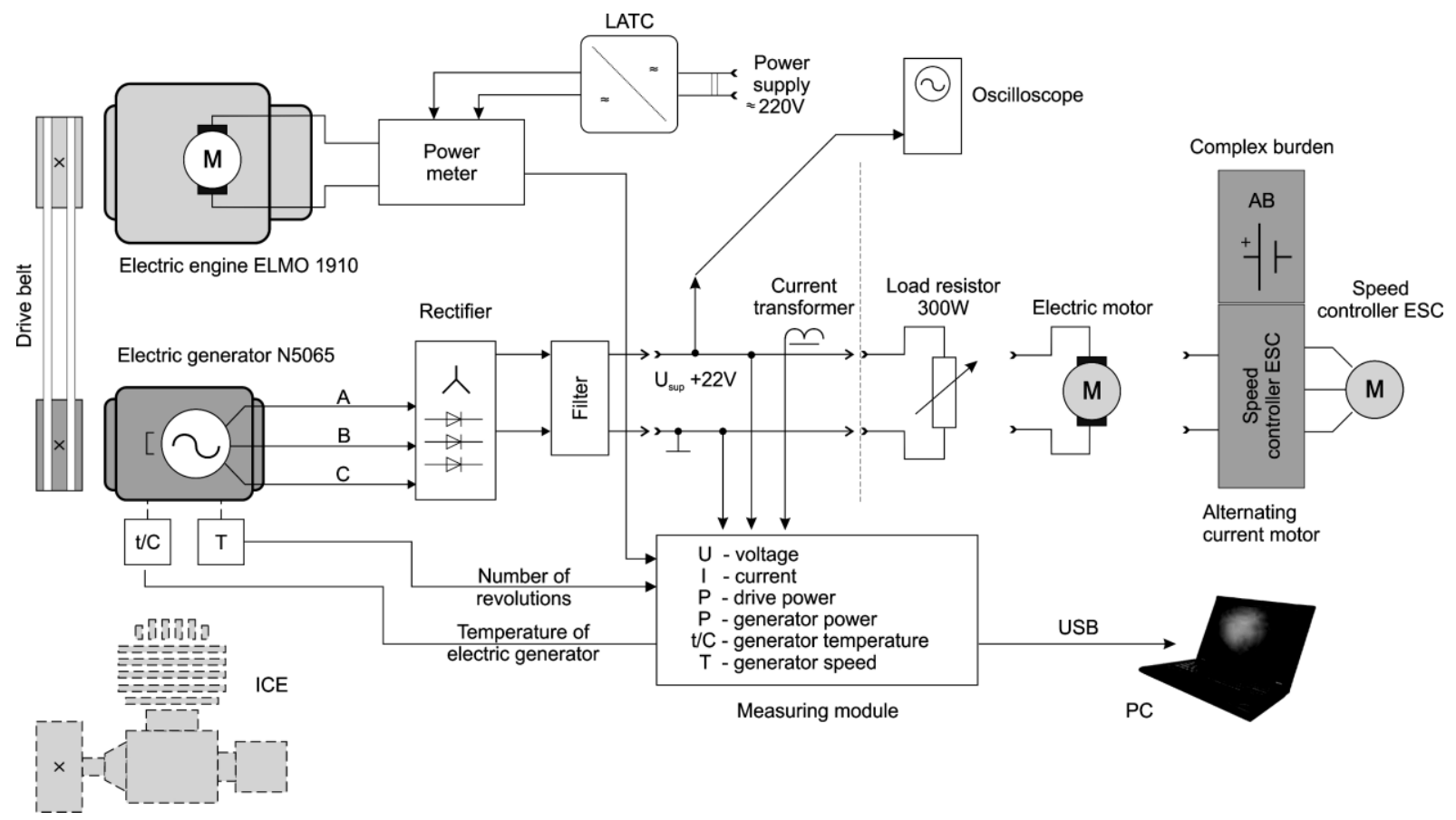

Fig. 3. The structural diagram of the stand for experimental testing of the modes of operation of the HE future mounts

Table 4 shows the composition of experimental modes for the testing stand of HE's future mounts

Table 4. The composition of experimental modes for the testing stand of HE's future mounts

\begin{tabular}{|c|c|}
\hline Device & Description \\
\hline LATC & Alternating current adjustable automatic transformer Delixi 25/250V 1000W \\
\hline ELMO 1019 & AC Driving Motor 220V 150W \\
\hline N5065 & Power Generator EMP N5065/05 KV410 with a voltage of 22V \\
\hline Rectifier & Three-phase diode rectifier AC \\
\hline Filter & LC-Filter for Smoothing Ripples of Rectified Voltage \\
\hline Power meter & Digital ACUTE 1020 \\
\hline Oscilloscope & Temperature sensor DS18B20 \\
\hline tO/C & Speed sensor RKP-MWES-LM393 \\
\hline T & Current transformer ACS712-30A \\
\hline Current sensor & Variable wire resistor 2-20 \\
\hline Load resistor & Ohm/300W \\
\hline Electric motor & DC electric motor as a reactive burden \\
\hline Complex burden & Rechargeable battery with ESC speed controller for multi-copter electric motor \\
\hline Measuring module & Atmega328p processor on the platform; Arduino Nano with display TC1602A-01T \\
\hline Tachometer & Revolution number meter, tachometer - UNI-T UT372 \\
\hline Multimeter & Digital Multimeter - UNI-T UT58B \\
\hline \multicolumn{2}{|c}{} \\
\hline
\end{tabular}

Figure 4 depicts a general view of the stand for experimental testing of the modes of operation for subsystems of the HE. 


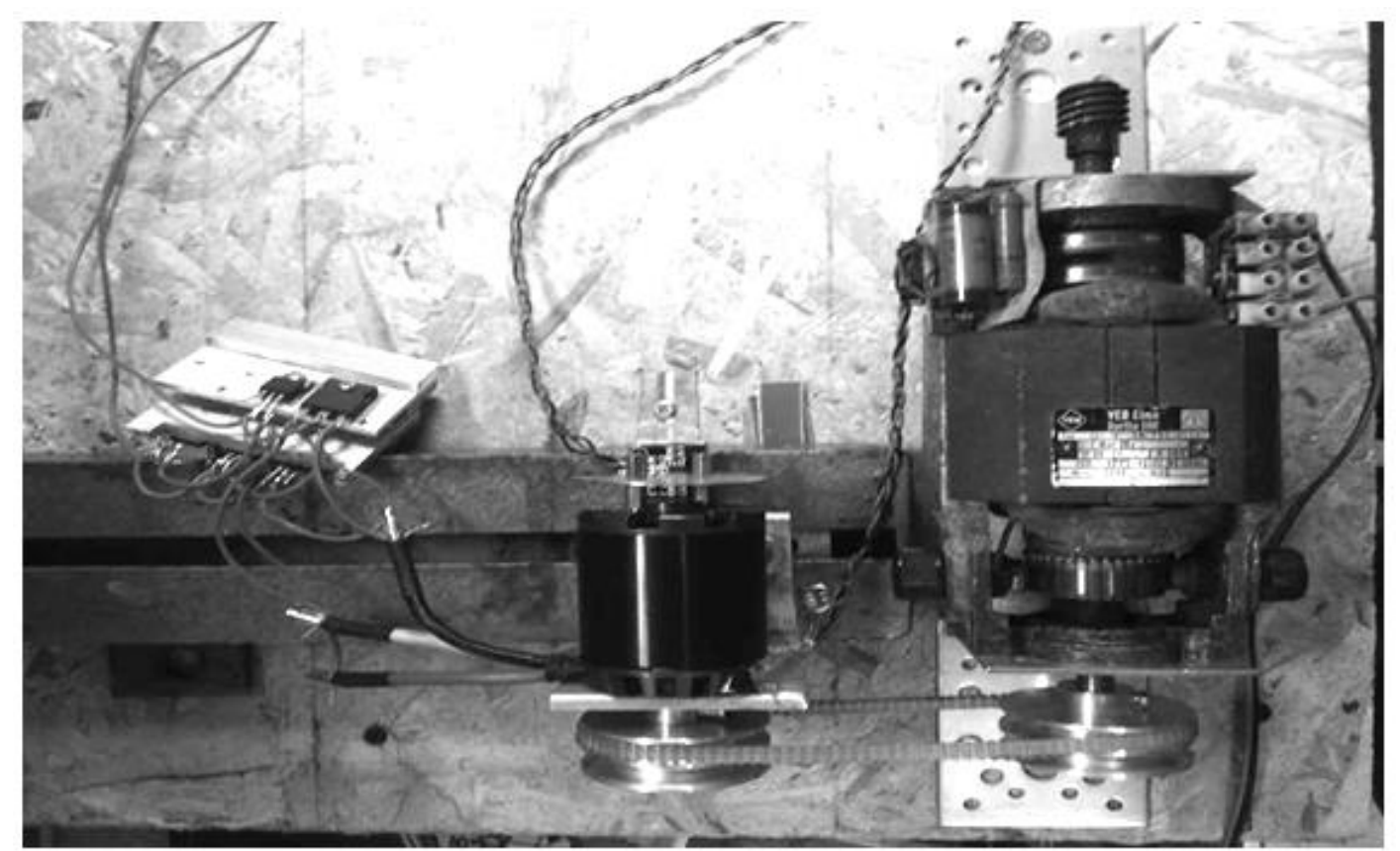

Fig. 4. The stand of experimental testing of modes for the future subsystems of the HE

The developed stand for experimental development and research of modes of operation of mounts and subsystems of the hybrid engine will allow:

- To determine their own load characteristics and investigate the dynamic processes of the generator at various revolutions with a drive from the primary engine;

- To test the automatic regulator of revolutions of the internal combustion engine at generator change of burden;

- To determine and perform a comparison of the quality and mass-dimensions of the subsystems of the hybrid engine;

- To test the starter modes of the hybrid engine, the modes of starting, warming up and transition to the generator mode of the internal combustion engine;

- To test the control algorithms of the charge-starting automatics of the hybrid engine.

Acknowledgment: This work was supported by Research Program under the budget program: 217 "Development of Science", subprogram 102 "Grant financing of scientific research" of Ministry of Education and Science of the Republic of Kazakhstan.

\section{References / Список литературы}

1. Carrillo L.R.G., Dzul A., Lozano R. Hovering Quad-Rotor Control: A Comparison of Nonlinear Controllers using Visual Feedback // IEEE Transactions Aerospace and Electronic Systems, 2012. № 48 (2). P. 31593170 .

2. Lee S.H., Kim Y. System Modeling and Waypoint Guidance Law Designing for 6-DOF Quadrotor Unmanned Aerial Vehicle // Journal of the Korean Society for Aeronautical and Space Sciences, 2013. № 41 (7). P. 305316.

3. Williams F.C., Laithwaite E.R., Eastham J.F. Development and design of spherical induction motors // Proceedings of the IEE-Part A: Power Engineering, 1959. № 106 (29). P. 471-484.

4. Rossini L., Mingard S., Boletis A., Forzani E., Onillon E., Perriard Y. Rotor Design Optimization for Reaction Sphere Actuator // IEEE Transactions Industry Applications, 2014. № 50 (4). P. 1706-1716.

5. Son H., Lee K-M. Open-Loop Controller Design and Dynamic Characteristics of a Spherical Wheel Motor // IEEE Transactions Industrial Electronics, 2010. № 57 (6). P. 3475-3482. 